\title{
Relative effects of inhaled corticosteroids on immunopathology and physiology in asthma: a controlled study
}

\author{
C M Burke, S Sreenan, S Pathmakanthan, Jennifer Patterson, Birgitta Schmekel,* \\ L W Poulter
}

\begin{abstract}
Background - Although corticosteroids are recognised as the most efficacious treatment for bronchial asthma, their mode of action remains unclear. A placebo controlled trial was undertaken of the effect of inhaled corticosteroids on physiological and immmunopathological parameters in asthmatic patients in whom the correlations between these indices were tested after treatment.

Methods - Sixteen patients (two women) with asthma entered a double blind, placebo controlled, parallel study during which they inhaled either budesonide $800 \mu \mathrm{g}$ twice daily or matching placebo for six weeks. Spirometric parameters and bronchial reactivity to histamine and terbutaline were measured and endobronchial biopsy samples were taken before and after treatment. Patients recorded morning and evening flow rates during the treatment period. The biopsy samples were subjected to immunohistological analysis to determine the disposition of inflammatory cells within the bronchial wall.
\end{abstract}

Results - Treatment with budesonide resulted in a significant improvement in the $25-75 \%$ forced expiratory flow $\left(\mathrm{FEF}_{25-75}\right)$ from a mean of $133 \mathrm{l} / \mathrm{min}$ before treatment to $1691 / \mathrm{min}$ after treatment, and in the morning peak expiratory flow rate (PEFR) from a mean of $384 \mathrm{1} / \mathrm{min}$ before treatment to $415 \mathrm{1} / \mathrm{min}$ after treatment. No changes were seen in the placebo group. Comparison between the changes in the immunopathological indices after six weeks of treatment with placebo or budesonide showed a significant reduction in the numbers of mast cells (0.5/unit area to 0.2 I unit area), activated eosinophils, and the expression of HLA-DR antigens (relative density -1.9 before to 1.02 after treatment) on inflammatory cells in response to treatment with budesonide. Although reductions in the numbers of other inflammatory cells within the bronchial wall were recorded using immunohistological analysis, these changes were not statistically significant. Significant correlations were found between changing immunological indices and lung physiology.

Conclusions - This controlled study shows that inhaled corticosteroids cause im- provement in physiological and immunopathological parameters in patients with stable asthma that are not seen with placebo, and that cause and effect relationships may exist between these two measures of disease status.

(Thorax 1996;51:993-999)

Keywords: inhaled corticosteroids, asthma, immunopathology, physiology.

It is only recently that the full nature of airway inflammation in asthma has been investigated in detail, using bronchoscopic techniques to obtain biopsy samples or bronchoalveolar lavage fluid. Such approaches have documented peribronchial inflammation in all asthmatic patients studied. ${ }^{1-3}$ The nature of this peribronchial immune response has been variously reported, highlighting increased numbers and upregulated activity of mast cells, ${ }^{4}$ eosinophils, ${ }^{45}$ and lymphocytes and macrophages, ${ }^{16}$ associated with increased expression of MHC class II antigens. ${ }^{1}$ Furthermore, structural changes including thickening of the basement membrane have been reported as consistent features in the bronchial wall of asthmatic subjects. $^{7}$

Corticosteroids are the single most efficacious treatment for bronchial asthma yet their mode of action remains poorly understood. How corticosteroids influence the immunopathology described above and promote clinical improvement remains in doubt. We and others have previously reported corticosteroid related effects on immunocompetent cells in asthma. ${ }^{8-11}$ However, the current placebo controlled study extends these observations by including further immunopathological indices and testing correlations between these indices and pathophysiological features of the disease.

Interpretation of the significance of airway inflammation in asthma is complicated by the failure of current data to demonstrate a clear relationship between pathological and physiological indices. In particular, the link between airway inflammation and bronchial hyperreactivity is not clear, despite reports of statistical correlations between bronchial reactivity and some inflammatory parameters. ${ }^{12}$

What is clear, however, is that asthma is consistently associated with abnormalities in both physiological and immunological mechanisms within the airways. ${ }^{12}$ Given the variable nature of the disease, clinically stable patients 
were recruited to try to sustain the placebo group for the duration of the protocol. The results show changes with time in both placebo and test groups. Interestingly, the most significant correlations were seen to occur between physiological indices and those aspects of cellular change most affected by corticosteroid treatment.

\section{Methods}

Eighteen patients (two women) were recruited. All patients had proven bronchial asthma (American Thoracic Society criteria) and were lifelong non-smokers. They were randomised into two groups, nine receiving budesonide while nine received placebo. Two patients were withdrawn from the placebo group, one for failure to attend a scheduled visit while the other deteriorated and needed inhaled steroids. The median (range) age was $28.7(23.2-45.1)$ years in the placebo group and 29.1 (19-38.1) years in the budesonide group. Median (range) duration of asthma was $4(0.2-17)$ years and 18 (5-29) years in the treatment and placebo groups, respectively. All patients were clinically stable for at least two months before the study and had no symptoms or signs of respiratory tract infection. No deterioration in asthma control, nor any inpatient or outpatient assessment or drug treatment (except $\beta_{2}$ agonist bronchodilators) occurred for at least two months before recruitment to the study. None of the patients had evidence of any respiratory or systemic disease apart from bronchial asthma and the chest radiograph was normal in all cases. Six of nine patients in the treatment group and four of seven subjects in the placebo group were atopic with a positive wheal of at least $3 \mathrm{~mm}$ in diameter larger than control to one or more common aeroallergens including house dust mite (Dermatophagoides pteronyssinus), grass pollen, tree pollen, and animal danders (Dome Hollister-Stier, Spokane, Washington, USA). No subject had a history of seasonal allergy and none were studied during the pollen season.

\section{STUDY DESIGN}

The study commenced with a two week run in period when patients were treated with inhaled terbutaline Turbohaler (Astra Pharmaceuticals, UK) $500 \mu \mathrm{g}$ 4-6 hourly as required for symptomatic control. Only those who reported symptoms of asthma and required extra terbutaline in addition to $500 \mu \mathrm{g}$ twice daily during the run in period were recruited. The patients then entered a double blind, randomised, parallel group study of six weeks duration during which they received either budesonide Turbohaler (Astra Pharmaceuticals, UK) $800 \mu \mathrm{g}$ twice daily or matching placebo. Treatment with terbutaline continued throughout the study as before. At the beginning and end of the six week period all subjects were assessed by baseline computerised spirometric testing, bronchial reactivity to histamine phosphate, and bronchodilator response to inhaled terbutaline.
Endobronchial biopsy samples were obtained before and after treatment and subjected to immunohistological analysis. Patients recorded morning and evening peak expiratory flow rate (PEFR) throughout the study period. The study was approved by the ethics committee of the James Connolly Memorial Hospital and informed consent was obtained from each patient.

\section{LUNG FUNCTION TESTS}

Baseline spirometric parameters were recorded at 09.00 hours on day 14 of the protocol following the two week run in period. The best of three valid attempts was recorded using a Gould 2400 computerised system. All patients abstained from their inhalers and from caffeine containing food and beverages for 12 hours before the study. After completion of baseline computerised spirometric testing a standardised bronchial provocation protocol was performed using nebulised buffered isotonic histamine phosphate solution (Abberwick Ltd, Ireland). ${ }^{1}$ After an initial nebulised saline challenge, doubling doses of histamine were administered via a Hudson nebuliser driven by oxygen at $7 \mathrm{l} / \mathrm{min}$. The aerosols were delivered straight into a face mask and inhaled by quiet tidal breathing for two minutes. The initial concentration of histamine phosphate was $0.03 \mathrm{mg} / \mathrm{ml}$. Spirometric values were recorded at 30 seconds and then every 60 seconds until a $20 \%$ fall in forced expiratory volume in one second $\left(\mathrm{FEV}_{1}\right)$ was achieved or the $\mathrm{FEV}_{1}$ returned towards the baseline value. The provocative concentration of histamine required to reduce $\mathrm{FEV}_{1}$ by $20 \%\left(\mathrm{PC}_{20} \mathrm{FEV}_{1}\right)$ was obtained from a concentration response curve. The $20 \%$ drop in $\mathrm{FEV}_{1}$ was calculated using the lowest $\mathrm{FEV}_{1}$ recorded after three technically correct manoeuvres following nebulised saline (control). On the following day (day 15) computerised spirometric tests were repeated in a similar fashion to day 14 . On this occasion the bronchodilator response to inhaled terbutaline $(1000 \mu \mathrm{g}$ via Turbohaler) was determined by repeating the spirometric tests after five minutes and then every 15 minutes after terbutaline for 60 minutes, and the maximum recorded increment in $\mathrm{FEV}_{1}$ over baseline was used to calculate the bronchodilator response.

All the above tests were performed again after six weeks of treatment using identical methods.

\section{FIBREOPTIC BRONCHOSCOPY}

Fibreoptic bronchoscopy (Olympus BF1T10) was performed 90 minutes after terbutaline inhalation on day 15 of the protocol and in identical fashion on day 57 . We have previously described our bronchoscopy protocol in detail. ${ }^{13}$ No premedication was given apart from terbutaline as described, and local anaesthesia of the upper respiratory tract and vocal cords was obtained with four puffs of lignocaine (Astra) aerosol spray (10 mg per puff) applied to the nasal cavity and vocal cords. Local anaesthesia of the lower respiratory tract was 
Table 1 Monoclonal antibodies used in the study

\begin{tabular}{|c|c|c|c|c|}
\hline Reagent & $C D$ & Source & Specificity in normal tissues & Reference \\
\hline $\mathrm{T} \operatorname{mix}$ & $\mathrm{CD} 2,5,8$ & RFHSM & All mature $T$ cells & 14 \\
\hline UCHL1 & CD45Ro & Dr P Beverley & $\mathrm{T}$ cell subset & 15 \\
\hline RFT4 & CD4 & RFHSM & Helper/induced $\mathrm{T}$ cell subset & 16 \\
\hline RFT8 & CD8 & RFHSM & Suppressor/cytotoxic $\mathrm{T}$ cell subset & 16 \\
\hline RFT1 & CD5 & RFHSM & Thymocyte T cells & 17 \\
\hline RFD7 & - & RFHSM & Mature macrophages & 18 \\
\hline RFD1 & - & RFHSM & $\begin{array}{l}\text { Epitope on class II MHC antigen with expression restricted to } \\
\text { dendritic cells and some B cells }\end{array}$ & 18 \\
\hline RFDR1 & - & RFHSM & Framework epitope on HLA-DR & 19 \\
\hline UCHM1 & CD14 & Dr N Hogg & Monocytes & 20 \\
\hline EG1 & - & $\begin{array}{l}\text { Pharmacia, } \\
\text { Sweden }\end{array}$ & Eosinophils & 21 \\
\hline EG2 & - & $\begin{array}{l}\text { Pharmacia, } \\
\text { Sweden }\end{array}$ & Activated eosinophils & 21 \\
\hline
\end{tabular}

RFHSM = Royal Free Hospital and School of Medicine.

achieved with $5 \mathrm{ml}$ aliquots of $0.5 \%$ lignocaine as required. Intravenous propovol (2, 6-diisopropylphenol (Zeneca, $\mathrm{UK}$ ) was given in an initial dose of $60 \mathrm{mg} / \mathrm{min}$ up to a maximum of $2 \mathrm{mg} / \mathrm{kg}$ until adequate sedation was achieved followed by an infusion at the rate of $5 \mathrm{mg} / \mathrm{kg}$ per hour to maintain the required level of sedation.

Endobronchial biopsy samples were obtained using standard Olympus spiked cupped forceps (Olympus FB22C) from segmental airways in the right upper lobe. A minimum of three samples was obtained from each patient in identical fashion at each bronchoscopy and immediately placed onto surgical gauze moistened with sterile physiological saline. Within 10 minutes of collection the specimens were immersed in Cryoembed (Brights Instrument Co, Huntingdon, UK) on a small cork disc and frozen in isopentane cooled in a bath of liquid nitrogen. Frozen specimens were stored in liquid nitrogen until use. Six micron cryostat sections were cut from all biopsy samples, air dried for one hour at room temperature, fixed in a 1:1 mixture of chloroform: acetone for five minutes, wrapped in "cling film", and stored at $-20^{\circ} \mathrm{C}$ until used.

\section{HISTOLOGICAL EXAMINATION}

Sections from all samples were stained with haematoxylin and eosin to reveal histological characteristics and with $0.1 \%$ toluidine blue to identify mast cells. Only those blocks containing samples of epithelium and lamina propria were used for immunohistological analysis. No tissues showing artefactual damage were used.

\section{IMMUNOCYTOCHEMICAL EXAMINATION}

Indirect immunoperoxidase methods were used to reveal specific cell types within the tissues. The monoclonal antibodies used are listed in table 1 . The incidence and distribution of specific cells was quantified using an image analyser (SeeScan Cambridge Ltd, Cambridge, UK) whereby the area of framed fields within the sections (three per slide) were point counted for positive cells. Using a $\times 40$ objective this represented approximately $20 \%$ of the tissue, sections of the biopsy specimens being approximately $0.5-1 \mathrm{~mm}^{2}$. The fields were selected from areas free from damage or cartilage.
In each measurement the number of cells counted was divided by the area of the frame (drawn to avoid artefact or cartilage) generated on the image of the field investigated. ${ }^{22}$ This reduced each framed area to unity. Results are expressed as cells $/ 10^{4} \mu \mathrm{m}^{2}$. HLA-DR expression was recorded as relative density of reaction product measured with the image analyser. ${ }^{23}$ In each specimen the optical density of the reaction product was measured in 10 fields selected at random but containing epithelium and lamina propria.

This process was also performed on sections incubated without monoclonal antibodies (negative controls). The difference in optical density between test and control preparations was taken as the relative absorption of reaction product resulting from expression of HLA-DR.

All monoclonal antibodies used in immunocytochemical methods and immunofluorescence (see below) were tested for specificity and appropriate dilution on sections of palatine tonsil. These controls included parallel studies of irrelevant monoclonal antibodies of the same isotype.

\section{IMMUNOFLUORESCENCE}

To demonstrate two cell associated antigens simultaneously "double" immunofluorescence methods were used. ${ }^{24}$ Appropriate combinations of two monoclonal antibodies (differing in isotype) were used as a first layer and the second layer consisted of a mixture of goat, anti-mouse $\operatorname{IgM}$ conjugated to fluorescein isothiocyanate (FITC) and goat anti-mouse IgG conjugated to tetramethylrhodamine isothiocyanate (TRITC). Proportions of relevant cells were calculated by counting all fluorescent cells on high power fields using a Zeiss fluorescence microscope fitted with epi-illumination and barrier filters of FITC and TRITC. This method was used to reveal (1) the CD4:CD8 ratio in the tissue; (2) the proportion of $\mathrm{CD} 8+$ $T$ cells expressing CD5; and (3) the proportion of macrophages expressing the suppressive phenotype $\mathrm{D} 1+\mathrm{D} 7+$. The following formulae were used for calculation:

(1) $\mathrm{CD} 4 / \mathrm{CD} 8$

(2) $\mathrm{CD} 8+\mathrm{CD} 5+/$ All CD8 $+\times 100$

(3) $\mathrm{D} 1+\mathrm{D} 7+1$ $(\mathrm{D} 1+)+(\mathrm{D} 7+)+(\mathrm{D} 1+\mathrm{D} 7+) \times 100$ 
Table 2 Median (range) physiological indices at baseline

\begin{tabular}{|c|c|c|}
\hline & Budesonide group $(n=9)$ & Placebo group $(n=7)$ \\
\hline $\begin{array}{l}\text { FVC }(\% \text { pred }) \\
\mathrm{FEV}_{1}(\% \text { pred) } \\
\left(\mathrm{FEV}_{1} / \mathrm{FVC}\right) \times 100 \\
\mathrm{FEF}_{25-75}(\% \text { pred }) \\
\mathrm{PEFR} \% \text { pred }) \\
\mathrm{BDR} \\
\mathrm{PC}_{20} \mathrm{FEV}_{1}(\mathrm{mg} / \mathrm{ml} \text { histamine })\end{array}$ & $\begin{array}{l}90(83-104) \\
80(44-100) \\
68(45-82) \\
48(14-82) \\
71(42-101) \\
21(0-61) \\
0.2(0.04-1.63)\end{array}$ & $\begin{array}{l}98(94-131) \\
89(65-122) \\
68(58-78) \\
47(30-96) \\
82(55-108) \\
16(14-31) \\
0.28(0.01-0.43)\end{array}$ \\
\hline
\end{tabular}

$\mathrm{FVC}=$ forced vital capacity; $\mathrm{FEV}_{1}=$ forced expiratory volume in one second; $\mathrm{FEF}_{25-75}=$ mid forced expiratory flow; $\mathrm{PEFR}=$ peak expiratory flow rate; $\mathrm{BDR}=$ bronchodilator response to terbutaline (\% increase in $\mathrm{FEV}_{1}$ ); $\mathrm{PC}_{20} \mathrm{FEV}_{1}=$ provocative concentration of histamine causing a $20 \%$ fall in $\mathrm{FEV}_{1}$.

These methods have been well tested in this and other laboratories over many years. No cross reactivity occurred between the class specific second layers as only affinity purified reagents were used (Southern Biotechnology, Alabama, USA).

\section{DATA ANALYSIS}

The quantification of all parameters was performed blind and the treatment code was not broken until all results were submitted for statistical analysis. Since $\mathrm{PC}_{20} \mathrm{FEV}_{1}$ data and peak flow measurements are known to be log normally distributed, the mean (SD) values were used in statistical tests. Other parameters were expressed as median and ranges and statistical tests for non-parametric analysis were employed.

The effects of budesonide treatment were tested using the Wilcoxon rank sum test to compare the relative changes after treatment between the budesonide treated and placebo treated groups. Where relevant, correlations were tested using Spearman's correlation coefficient.

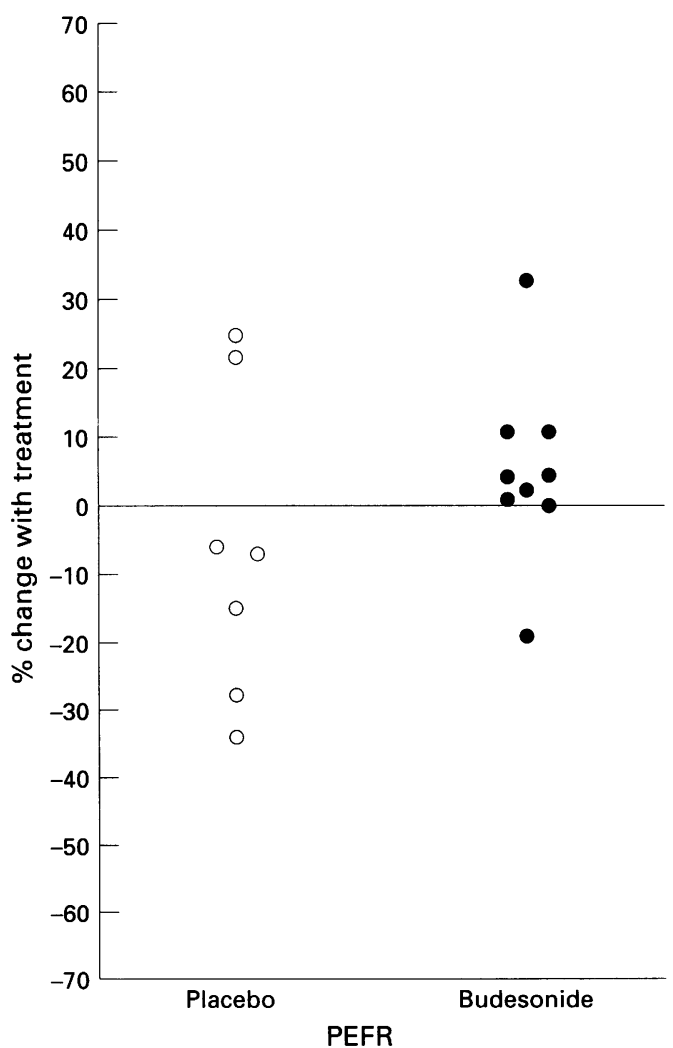

\section{Results}

PULMONARY FUNCTION TESTS

On entry to the study there was no significant difference in the physiological indices between the groups (table 2). By the end of the study the changes in $\mathrm{FEF}_{25-75}$ values were significantly greater in subjects receiving budesonide than in those who received placebo: $146 \mathrm{l} / \mathrm{min}$ before treatment and $140 \mathrm{l} / \mathrm{min}$ after treatment in the placebo group and $133 \mathrm{l} / \mathrm{min}$ before treatment and $169 \mathrm{l} / \mathrm{min}$ after treatment in the budesonide group. Morning PEFR values in the placebo group were $442 \mathrm{l} / \mathrm{min}$ before treatment and $414 \mathrm{l} / \mathrm{min}$ after treatment, and in the budesonide group were $384 \mathrm{1} / \mathrm{min}$ before treatment and $415 \mathrm{l} / \mathrm{min}$ after treatment $(\mathrm{p}=0.02$ and $\mathrm{p}=$ 0.04 , respectively; fig 1). Overall, therefore, a $27 \%$ increase in $\mathrm{FEF}_{25-75}$ and an $8.2 \%$ increase in PEFR were seen after steroid treatment. Bronchodilator responsiveness changed from a median of $21 \%$ to $8 \%$ in the treatment group and from $16 \%$ to $20.5 \%$ in the placebo group. $\mathrm{PC}_{20} \mathrm{FEV}_{1}$ was improved in the treatment group from a geometric mean $0.22 \mathrm{mg} / \mathrm{ml}$ to $0.35 \mathrm{mg}$ / $\mathrm{ml}$, but in the placebo group it deteriorated from $0.28 \mathrm{mg} / \mathrm{ml}$ to $0.25 \mathrm{mg} / \mathrm{ml}$. These differences were not statistically significant. No other changes in physiological indices showed any difference between the budesonide and placebo treated groups.

\section{HISTOLOGICAL EXAMINATION}

Histological examination of biopsy samples taken before treatment showed evidence of chronic inflammation with accumulations of mononuclear cells in the subepithelial tissue

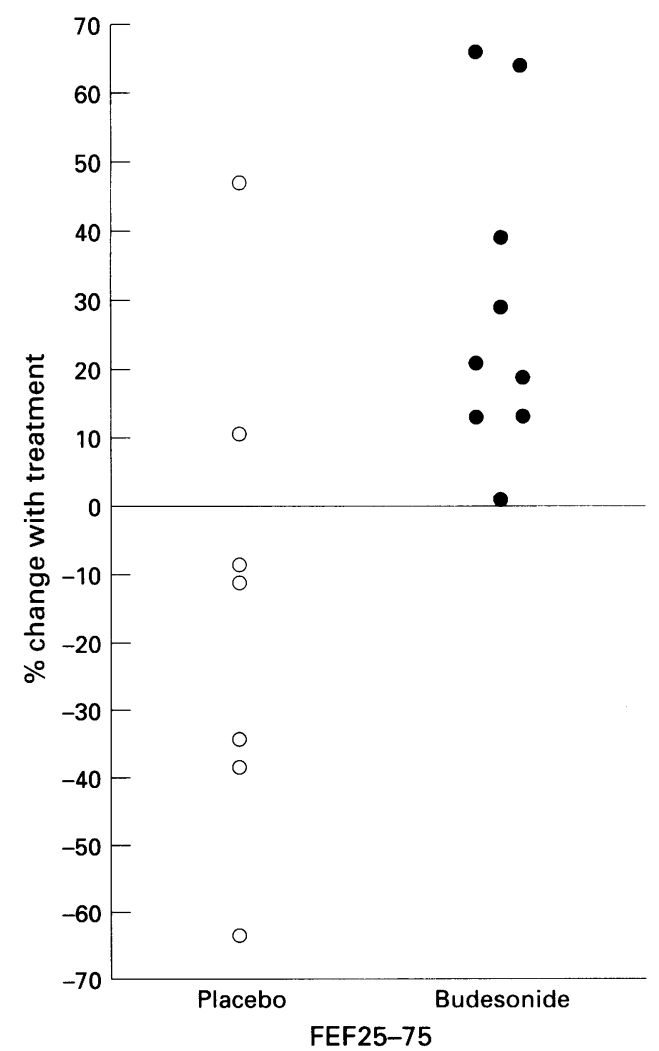

Figure 1 Percentage changes from baseline in peak expiratory flow rate (PEFR) and 25-75\% forced expiratory flow $\left(F E F_{25-75}\right)$ following treatment for six weeks with inhaled budesonide or placebo. 
Table 3 Median (range) baseline values of the immunopathological analysis

\begin{tabular}{lccccc}
\hline & \multicolumn{2}{l}{ Budesonide group $(n=9)$} & & Placebo group $(n=7)$ \\
\cline { 2 - 3 } \cline { 5 - 6 } & Pre & Post & Pre & Post \\
\hline T cells & $3.1(1.9-6.7)$ & $2.3(1.2-4.7)$ & & $3.8(2.0-16.6)$ & $3.7(1.7-9.2)$ \\
CD45Ro+T cells* & $2.3(1.3-6.0)$ & $2.0(1.1-4.7)$ & & $3.5(1.4-11.8)$ & $2.7(1.2-8)$ \\
RFD1+ VE macrophages* & $1.6(1.0-2.2)$ & $1.4(0.6-2.4)$ & & $2.1(1.1-4.0)$ & $1.7(0.8-2.7)$ \\
RFD7+VE macrophages* & $2.0(0.9-2.8)$ & $1.9(1.4-3.7)$ & & $1.8(1.2-3.8)$ & $1.9(1.5-4.3)$ \\
CD14* & $0(0-0.9)$ & $0.3(0-1.0)$ & & $0.7(0-1.5)$ & $1.0(0-2.4)$ \\
EG1* & $1.0(0-3.9)$ & $0.5(0-1.5)$ & & $1.6(0.8-3.1)$ & $1.7(1.3-3.7)$ \\
EG2* & $0.2(0-3.1)$ & $0.2(0-0.8)$ & & $0.6(0-2.1)$ & $1.2(0.5-2.7)$ \\
Mast cells* & $0.5(0-1.8)$ & $0.2(0-0.9)$ & & $0(0-1.4)$ & $0.8(0-1.7)$ \\
CD4/CD8 ratio & $3.0(0.5-5.0)$ & $2.25(1.0-4.0)$ & & $2.9(0.71-4.0)$ & $1.75(0.8-4.0)$ \\
CD5+ (as \% of CD8+) & $15.0(10-25)$ & $10(0-20)$ & & $8.0(0-60)$ & $10(10-60)$ \\
D1+D7+ (as \% of macrophages) & $25.0(20-32)$ & $35(25-37)$ & & $26.0(20-31)$ & $31(26-40)$ \\
HLA-DRt & $1.9(1.08-4.41)$ & $1.02(0.22-2.85)$ & & $1.68(1.36-3.3)$ & $1.94(1.02-2.98)$ \\
\hline
\end{tabular}

* cells $/ 10^{4} \mu \mathrm{m}^{2} ; \dagger$ relative density.

and thickening of the area adjacent to the epithelium in all cases. After treatment no gross changes were observed in the placebo group while three of nine in the steroid treated group exhibited a clear reduction in the extent of the inflammation.

Numbers of mast cells in the steroid treated group fell from a median of 0.5 (range $0-1.8$ ) to $0.2(0-0.9)$ cells $/ 10^{4} \mu \mathrm{m}^{2}$ while mast cell numbers increased in the placebo group from $0(0-1.4)$ to $0.8(0-1.7)$ cells $/ 10^{4} \mu \mathrm{m}^{2}$. This represents a significant difference between the treatment and placebo groups $(\mathrm{p}<0.005)$.

\section{IMMUNOHISTOLOGICAL EXAMINATION}

All immunohistological indices were comparable between groups at the beginning of the treatment period (table 3). After treatment seven of the nine steroid treated patients showed reductions in $\mathrm{T}$ cells per unit area, but reductions in this parameter were also recorded in five of seven placebo treated subjects and comparison between budesonide and placebo treatment showed no significant difference. The effect of budesonide was not significantly different from the effect of placebo with respect to the numbers of CD45Ro + T cells, CD14+ cells, RFD1 + cells, RFD7 + cells, CD4:CD8 ratio, or proportions of $\mathrm{D} 1+\mathrm{D} 7+$ suppressive cells (table 3 ).

The median (range) numbers of activated eosinophils increased in the placebo group over the period of the study from $0.6(0-2.1)$ to $1.2(0.5-2.7)$ cells $/ 10^{4} \mu \mathrm{m}^{2}$ while there was no change in the budesonide group $0.2(0-3.1)$ to $0.2(0-0.8)$ cells $/ 10^{4} \mu \mathrm{m}^{2}$. When comparing budesonide treatment with placebo, there was a significant difference $(\mathrm{p}<0.02)$.

Median (range) values of HLA-DR expression showed a small increase in relative density in the placebo group from 1.68 (1.36$3.3)$ to $1.94(1.02-2.98)$ yet fell to half the original values in the steroid treated subjects from $1.9(1.08-4.41)$ to $1.02(0.22-2.85)$ $(\mathrm{p}<0.05)$.

\section{CORRELATIONS}

Using the entire group of 16 subjects correlations were sought between the changes in immunological indices before and after treatment and changes in physiological measurements. All possible combinations were
Table 4 Correlations between changes in immunological and physiological indices in asthma

\begin{tabular}{lll}
\hline Comparison of changes with treatment & $R$ value & $p$ value \\
\hline Mast cell numbers $v \operatorname{FEV}_{1}(\mathrm{n}=16)$ & -0.633 & $<0.01$ \\
Mast cell numbers $v$ PEFR $(\mathrm{n}=16)$ & -0.650 & $<0.01$ \\
Mast cell numbers $v$ FEF $_{25-75}(\mathrm{n}=16)$ & -0.508 & $<0.05$ \\
$\mathrm{D} 1+\mathrm{D} 7+(\%) v \mathrm{PC}_{20} \operatorname{FEV}_{1}(\mathrm{n}=11)$ & 0.605 & $<0.05$ \\
\hline
\end{tabular}

$R=$ Spearman's correlation coefficient $\mathrm{FEV}_{1}=$ forced expiratory volume in one second; $P E F R=$ peak expiratory flow rate; $\mathrm{FEF}_{25-75}=$ forced mid expiratory flow; $\mathrm{PC}_{20} \mathrm{FEV}_{1}=$ provocative concentration of histamine causing a $20 \%$ fall in $F_{E V}$.

tested, but only four exhibited a significant relationship. Changes to mast cell numbers were inversely related to $\mathrm{FEV}_{1}, \mathrm{PEFR}$, and $\mathrm{FEF}_{25-75}$, while a direct relationship was seen between changes in the percentage of $\mathrm{D} 1+\mathrm{D} 7+$ macrophages and $\mathrm{PC}_{20} \mathrm{FEV}_{1}$ (table 4).

\section{Discussion}

This controlled study details the physiological and immunopathological impact of corticosteroids in bronchial asthma. Our results show a significant improvement in $\mathrm{FEF}_{25-75}$ and morning PEFR values, together with significant reductions in mast cells, activated eosinophils, and MHC class II expression mediated by corticosteroids. No significant changes in FVC, $\mathrm{FEV}_{1}$ or the $\mathrm{FEV}_{1} / \mathrm{FVC}$ ratio were observed. The failure of corticosteroids to improve $\mathrm{FEV}_{1}$ is not surprising given the good baseline $\mathrm{FEV}_{1}$ values in these clinically stable patients. Also, the allowed use of $\beta_{2}$ agonists as required may have reduced the variance between test and placebo groups as the control group could have compensated by greater use of the Turbohaler. This was not specifically monitored. We have previously reported an increase in $\mathrm{FEF}_{25-75}{ }^{8}$ associated with inhaled corticosteroids and those preliminary observations are confirmed in this controlled study. Our current results are also consistent with other reports of improved spirometric variables associated with corticosteroids. ${ }^{92526}$ Variability in PEFR and, in particular, reduction in the morning values (the so-called "morning dip") is characteristic of bronchial asthma. Variability in PEFR mirrors the clinical severity of asthma and correlates with bronchial hyperreactivity. ${ }^{27}$

In general terms, increase in morning PEFR reflects improved asthma control and the improved morning peak flow values achieved by 
budesonide are consistent with the efficacy of corticosteroids in asthma. Although bronchial reactivity is generally accepted as the best physiological index of asthma severity, the effect of corticosteroids on bronchial responsiveness is controversial. ${ }^{28} \mathrm{We}$ and others have reported moderate downregulation of bronchial hyperreactivity by inhaled corticosteroids, ${ }^{82629}$ but conflicting data have been recorded. ${ }^{30}$ Our current results show improvement in bronchial reactivity to both histamine and terbutaline which do not attain statistical significance. This is perhaps not surprising given the stable nature of our subjects at the start of the study.

The significant reduction seen in mast cell numbers after budesonide treatment is consistent with previous reports. ${ }^{26}$ It is noted, however, that much of the difference seen between test and control groups in the present study resulted from an increase in cell numbers in the placebo group. Such observations are of interest, however, as mast cell involvement in asthma has been more associated with acute symptomatic events while steroid treatment is thought to have its greatest effect on the chronic underlying inflammation. The current results also show a significant reduction of activated eosinophils in the bronchial wall following inhaled corticosteroids. This supports previous uncontrolled reports ${ }^{89}$ in suggesting that the efficacy of corticosteroids in asthma may in part be related to downregulation of eosinophils and their products. A predominance of eosinophils in asthmatic inflammation is well recognised, ${ }^{5}$ these cells being particularly associated with acute exacerbations following antigen challenge. ${ }^{31}$ Downregulation of eosinophil activation by steroids may contribute to reducing bronchial inflammation as products of activated eosinophils such as cationic protein are toxic and thought to mediate the bronchial epithelial damage characteristic of asthma. ${ }^{3233}$

The current data do not demonstrate how corticosteroids may affect mast cells and eosinophils. A direct effect of the drug on these cells cannot be excluded. However, as corticosteroids have been shown to regulate T lymphocyte activation ${ }^{34}$ it may be via this indirect route that steroids affect these granulocytes. It has been suggested that specific cytokines from $T$ cell subsets are responsible for recruiting and activating granulocytes, ${ }^{35}$ thus any downregulation of $T$ cell activity by steroids might well lead in turn to downregulation of mast cell and eosinophil activity. ${ }^{36}$ No significant steroid related fall in $\mathrm{T}$ cell numbers was seen. This observation might imply that reduced cytokine production can be induced by corticosteroids. The observed reduction of HLA-DR expression in the lamina propria following budesonide treatment would add weight to the argument that $T$ cell activation is downregulated. Whether this regulation in class II MHC expression is occurring on the $T$ cells and/or represents a reduction in numbers of antigen presenting cells present in the tissue remains unknown. Ideally "double fluorescence" should be performed to identify the class II MHC positive population. The extent of HLA-DR expression and close proximity of cells makes this difficult. Both of these phenomena are, however, reputed effects of steroid therapy ${ }^{8}$ and would be inevitably associated with reduced inflammation. In this regard it is interesting that the only correlations between revealed physiological and immunopathological parameters involved those features significantly altered by steroid therapy. This observation supports the contention that corticosteroids may affect physiology via their effects on underlying bronchial inflammation.

There is no doubt that further studies to determine the impact of corticosteroids and other drugs on $\mathrm{T}$ cells and cytokine release are indicated. However, to avoid false interpretation such studies should be carefully controlled given the characteristic variability of asthma. In particular, the changes seen in our placebo group confirm that variability in inflammatory parameters occurs over a short period in asthma patients who are not taking anti-inflammatory medication. It is possible that further effects of corticosteroids might be demonstrated by selection of less clinically stable patients with more margin for improvement. However, since the protocol included bronchoscopy and biopsy on two occasions in a control group maintained on $\beta_{2}$ agonist bronchodilators alone, selection of clinically unstable patients was not ethically acceptable.

The authors thank Dr Tom Hogan, consultant anaesthetist, and Ms Condez, Ms Suzanne Doyle, Nurse Mary Toole, and Ms Paula Hearne for their valuable technical assistance, and gratefully acknowledge the support of the Eastern Health Board, Dublin and Astra Pharmaceuticals, Draco.

1 Poulter LW, Power C, Burke CM. The relationship between bronchial immunopathology and hyper-responsiveness in asthma. Eur Respir $\mathcal{f}$ 1990;3:792-9.

2 Beasley R, Roche WR, Roberts JA, Holgate ST. Cellular events in the bronchi in mild asthma and after bronchial events in the bronchi in mild asthma and after bro
provocation. Am Rev Respir Dis 1989;139:806-17.

3 Jeffrey PK, Wardlaw AJ, Nelson FC, Collins JV, Kay AB Bronchial biopsies in asthma. Am Rev Respir Dis 1989 140:1745-53.

4 Wardlaw AJ, Dunnette S, Gleich GJ, Collins JV, Kay AB Eosinophils and mast cells in bronchoalveolar lavage in subjects with mild asthma. Am Rev Respir Dis 1988;137: $62-9$.

5 Bousquet J, Chanez P, Lacoste JY, Barneon G, Ghavanian $\mathrm{N}$, Enander I, et al. Eosinophilic inflammation in asthma. N Engl F Med 1990;323:1033-9.

6 Poulter LW, Power C, Hutter C, Sreenan S, Burke C. T cells and other mononuclear cells in asthma. In: Kummer, cells and other mononuclear cells in asthma. In: Kummer, ed. Asthma immunopathology and im

York, Vienna: Springer-Verlag, 1993.
Roche WR, Beasley R, Williams JH, Holgate ST. SubRoche WR, Beasley R, Williams JH, Holgate ST. Sub-
epithelial fibrosis in the bronchi of asthmatics. Lancet 1989;i:520.

8 Burke CM, Power C, Norris A, Schmekel B, Condez A Poulter LW. Lung function and immunological changes of inhaled corticosteroid therapy in asthma. Eur Respir 1992;5:73-9.

9 Djukanovic R, Wilson J, Britten $\mathrm{K}$, Wilson SJ, Walls AF, Roche WR, et al. Effect of an inhaled corticosteroid on airway inflammation and symptoms in asthma. Am Rev Respir Dis 1992;45:669-74.

10 Adelroth E, Rosenhall L, Johansson SA, Linden M, Venge P. Inflammatory cells and eosinophilic activity in asthmatics investigated by bronchoalveolar lavage. The effects of antiasthmatic treatment with budesonide or terbutaline. $\mathrm{Am}$ asthmatic treatment with budeso

11 Jeffrey PK, Godfrey RW, Adelroth E, Nelson F, Rogers A, Johansson SA. Effects of treatment on airway inflammation and thickening of basement membrane reticular collagen in asthma. A quantitative light and electron microscopic study. Am Rev Respir Dis 1992;145:890-9.

12 Durham SR, Kay AB. Eosinophils, bronchial hyperactivity and late phase asthmatic reactions. Clin Allergy 1985;15 411-8.

13 Clarkson K, Power CK, O'Connell F, Pathmakanthan S Burke CM. A comparative evaluation of propofol and midazolam as sedative agents in fibreoptic bronchoscopy. Chest 1993;104:1029-31.

14 Poulter LW, Campbell DA, Munro C, Janossy G. Discrimination to macrophages and dendritic (ID) cells of 
man using monoclonal antibodies. Scand f Immunol 1986; 24:351-7.

15 Smith SH, Brown MH, Rowe D, Callord RE, Beverley PCL. Functional subsets of helper-inducer cells defined by a new monoclonal antibody, UCHL1. Immunology 1986;58:63-70.

16 Janossy G, Prentice HG. T cell subpopulations, monoclonal antibodies and their therapeutic applications. Clin Haema tol 1982;11:631-61.

17 Batori G, Bofill M, Petrdyi G, Bollan SR, Janossy G. Comparative analysis of monoclonal antibodies of workshop $\mathrm{T}$ series on suspensions and tissue sections. In Bernard A, ed. Leucocyte typing. Paris: Springer-Verlag, 1984:469-75

18 Hogg N, MacDonald S, Slusdrenko M, Beverley PCL. Monoclonal antibodies specific for human monocytes, granulocytes, and endothelium. Immunology 1984;53:75367.

19 Poulter LW, Campbell DA, Munro CD, Buthcher RG. The quantification of HLA-DR expression on human cells
using immunocytochemistry. $\mathcal{F}$ Immunol Methods $1987 ; 98$ : using

20 Granger S, Janossy G, Francis G, Blacklock H, Poulter LW. Elimination of $\mathrm{T}$ Iymphocytes from human bone marrow with monoclonal $\mathrm{T}$ antibodies and cytolytic complement. Br $\mathcal{F}$ Haematol 1982;50:367.

21 Tai PC, Spry CJF, Peterson C, Venge P, Olsson I. Monoclonal antibodies distinguish between storage and secreted forms of eosinophils cationic protein. Nature 1984;309: forms $182-4$.

22 Poulter LW, Norris A, Power C, Condez A, Barnes H, Schmekel B, et al. $T$ cell dominated inflammatory reaction in the bronchioles of asymptomatic asthmatics are also present in the nasal mucosa. Postgrad Med $\mathcal{F}$ 1991;67: 747-53.

23 Power CK, Burke CM, Sreenan S, Hurson B, Poulter LW. $T$ cell and macrophage subsets in the bronchial wall of clinically healthy subjects. Eur Respir f 1994;7:437-41.

24 Janossy G, Bofill M, Poulter LW. Two colour immunofluorescence: analysis of the lymphoid system with monoclonal antibodies. In: Polack J, van Noorden S, eds. Immunocytochemistry: practical applications in pathology and biology. 2nd edn. Bristol: J Wright PSG: 1986.
25 Townley RG, Reeb R, Fitzgibbons T, Adolpson RL. The effects of corticosteroids on the beta adrenergic receptors ;45:118-21.

26 Laitinen L, Laitinen A, Hanhtela T. A comparative study of the effects of inhaled corticosteroid, budesonide, and a $\beta_{2}$ agonist, terbutaline, on airway inflammation in newly diagnosed asthma: a randomised, double-blind, parallelgroup controlled trial. $\mathcal{\exists}$ Allergy Clin Immunol 1992;90 $32-41$.

27 Ryan G, Latimer KM, Dolovich J, Hargreave FE. Bronchia responsiveness to histamine: relationship to diurnal variation of peak flow rate, improvement after bronchodilator, and airway calibre. Thorax 1982;37:423-9.

28 Ryan G, Latimer K, Juniper E, Roberts R, Tech M, Hargreave $F$. Effect of beclomethasone dipropionate on bronchial responsiveness to histamine in controlled non steroiddependent asthm. 7 Allergy Clin Immunol 1985;75:25-30.

29 McFadden ER Jr. Corticosteroids and cromolyn sodium modulators of airway inflammation. Chest 1988;94:181-4.

30 Jenkins $C R$ Woolcock AJ. Effect of prednisolone and beclomethasone dipropionate on airway responsiveness in methasone dipropionate on airway responsiveness
asthma: a comparative study. Thorax 1988;43:378-84.

31 Rossi GA Crimi E, Lantero S, Gianiori P, Late phase asthmatic reaction to inhaled allergen is associated with asthmatic reaction to inhaled allergen is associated with early recruitment of eosinop

32 Gleich GJ, Flavahan NA, Fujusawa T, Vanhoutte PM. The eosinophil as a mediator of damage to respiratory The eosinophil as a mediator of damage to respirac

33 Gleich GJ, Frigas E, Loegering DA, Wassom DL, Steinmuller D. Cytotoxic properties of eosinophil major basic muller $\mathrm{D}_{\dot{f}}$. Cytotoxic properties of e

34 Robinson D, Hamid O, Sun Ying, Bentley A, Assoufi B, Durham S, et al. Prednisolone treatment in asthma i associated with modulation of bronchoalveolar lavage cel interleukin 4 , interleukin 5 and interferon gamma cytokin gene expression. Am Rev Respir Dis 1993;148:401-6.

35 Wierenga A, Snoek M, De Groot C, Chretien L, Bos JO Jansen $\mathrm{HM}$, et al. Evidence for compartmentalization of functional subsets of CD4 $+\mathrm{T}$ lymphocytes in atopic patients. F Immunol 1990;144:4651-6.

36 Corrigan CJ, Halzku A, Gemov-Engesueth V, Doi S, Kikuch $\mathrm{Y}$, Takatsu $\mathrm{K}$, et al. CD4 T lymphocyte activation in asthma is accompanied by increased serum concentration of interleukin 5: effect of glucocorticoid therapy. $\mathrm{Am} \mathrm{Rev}$ Respir Dis 1993;147:540-7. 